tion proposed by some that the latitude and longitude of an object, large or small, be translated into a literal code, is not satisfactory at least at the present time. We do not have the system of lunar coordinates adequately defined to make such alpha-numeric systems practical.

"There is one final point to emphasize concerning our selection of names. We shall continue to exclude all political figures, national heroes, religious figures, and modern philosophers. Ancient philosophers and various legendary figures will be accepted, however."

The subsequent phases of the work following this interim-report will be presented at the general Assembly, Sydney, Aug. 1973.

GROUPE DE TRAVAIL "FiguRES, MOUVEMENTS ET POSITIONS OBSERVÉS DE LA LUNE"

Th. Weimer (Chairman), 16 members and 9 consultants.

Several lists of bibliographic references on current publications and reports on the figure of the Moon cartography and selenodesy were circulated for the Members.

A sub-group was appointed to study a list of selected craters for geodetic purposes, and the problem of a unified lunar coordinate system. The members are: Weimer, Moutsoulas, Gavrilov.

Th. Weimer, Chairman of the W.G., reports:

"Entre septembre 1970 et octobre 1972, le bulletin bibliographique du groupe a analysé 160 articles ou mémoires; 57 concernaient la cartographie et la sélénodésie, 15 la rotation de la Lune, 88 son orbite et son potentiel gravitationnel.

"La télémétrie par laser sur laquelle on fonde de grands espoirs n'est qu'à son début et ne pourra de sitôt remplacer complètement les méthodes photographiques classiques utilisées en sélénodésie et en cartographie.

"Le Groupe de Travail a participé à l'organisation de certaines recherches:

" $\left(1^{\circ}\right)$ en émettant à l'Assemblée Générale de 1970 un voeu pour le dépôt d'un plus grand nombre de cataphotes sur la Lune.

“ $\left(2^{\circ}\right)$ en élaborant une liste de cratères qui servira de base à un catalogue de coordonnées de points fondamentaux sur la Lune, catalogue indispensable pour la sélénodésie et la cartographie de haute précision. Les voies et manières nécessaires pour transformer cette liste en catalogue de cratères fondamentaux feront l'object de travaux du groupe dans les mois à venir, afin que des propositions concrètes puissent être présentées à l'Assemblée Générale de Sydney (1973)."

About the occultation observations program, J. D. Mulholland reports:

"A program of high-speed photoelectric occultation timings is being pursued at the McDonald Observatory. These measures provide the occultation event time with a resolution of 1 millisecond, corresponding to a linear distance of about 1 meter at lunar distance. In addition, one obtains a value for the slope of the lunar limb at that point. The limb slope measures do correlate with the known limb profiles. We are preparing to discuss these occultation observations and those of grazing occultations in combination with the laser ranges. This will provide rather high resolution in all three coordinates, although the uncertainties in the limb profile must be recognized as a limiting factor. Nonetheless, the development of an extremely high-precision numerical ephemeris seems to be very near."

Mrs. F. M. Sadler, from H.M. Nautical Almanac Office, Royal Greenwich Observatory, summarizes as follows:

"At present about 9000 observations of lunar occultations are being received annually; this high number is due in part to several passages of the Pleiades. The observations are reduced on receipt and the results sent to the observers. The analysis of 40000 occultations for the period 1943-1972 has been completed and the resulting corrections to the mean lunar elements (due to Brown) will be published shortly. One important result, found from the analysis, is that the tidal deceleration of the Moon in mean longitude is $-21^{\prime \prime}\left( \pm 2^{\prime \prime}\right) T^{2}$ where $T$ is in centuries. Analysis of grazing occultations shows that the position angles of C. B. Watts' charts of the marginal zone requires a correction of $-0^{\circ} 25\left( \pm 0^{\circ} 01\right)(03 \cdot 094 \cdot 254)$. 
"The contours of Watts' charts have been transformed into tables of rectangular co-ordinates. These co-ordinates are recorded on magnetic tape, and can be transferred to one exchangeable-disc cartridge thus allowing random access to every chart."

A report from W. L. Sjogren summarizes some results as follows:

"Lunar Physical Shape: Data from the laser altimeter aboard Apollo 15 and 16 have provided two complete profiles of lunar topography. Elevations are established at approximately every $30 \mathrm{~km}$ or one degree of longitude. One profile is at a $25^{\circ}$ inclination and the other is at $-10^{\circ}$ inclination with a latitude displacement of $35^{\circ}$ near the prime meridian. Mare Serenitatis, Crisium and Smythii are relatively flat with Mare Smythii the lowest basin. Lunar elevations on ACIC lunar charts do not agree in some areas (i.e. Ptolemaeus-Nubium, $2 \mathrm{~km}$, and the Mare Tranquillittatis region near Theophilus, 2-3 km).

"Solution for the lunar radius of a best fitting sphere was $1737.4 \mathrm{~km}$, having a center of mass offset of $2.5 \mathrm{~km}$ toward the earth, $1.2 \mathrm{~km}$ east and $1.0 \mathrm{~km}$ south. Of course the new reference system being initiated by Moutsoulas should use these new elevation points as strong ties for the global figure.

"Lunar Gravitation Field: Analysis of radio tracking data from Apollo 12-16 has revealed many new facts about the mascons and other surface features. Detailed gravity profiles obtained for Serenitatis, Nectaris and Crisium indicate that these mascons are relatively near surface features, disk shaped with tapering edges, all having a mass distribution of 800 kilograms per $\mathrm{cm}^{2}$. The subsatellite from Apollo 15 has provided new data at low altitude $(40-60 \mathrm{~km})$ over the southern hemisphere (to $30^{\circ} \mathrm{S}$ latitude). Nectaris, Humorum and Orientale have been mapped in detail. Grimaldi has a positive anomaly - the smallest mascon. All large craters observed have negative anomalies. The Apollo 16 subsatellite will provide a profile at an $11 \mathrm{~km}$ altitude over Copernicus. The central highlands, the Apennines, and the Marius Hills are positive anomalies. The Altai scarp marks a definite positive ridge in the highlands. The Apennines appear to have had considerable isostatic compensation where as the Marius Hills have not.

"Surface gravity measurements using the accelerometers on the lunar module have correlated well with orbital results.

"Normal points formed on orbits of the Apollo 15 subsatellite data will provide indirect data for the farside gravity field. Some 4000 consecutive free fall orbits must be predicted with a gravity model. We should see improvements over the JPL 15-8 and the Langley 13-13 spherical harmonic models.

"Some 600 surface disks have been estimated to describe the front side local gravity field using primarily the old Lunar Orbiter data. This will be updated with the subsatellite data. Future efforts should be directed towards obtaining direct measurements of farside gravity. If the regions like Hertzsprung, Korolev, and the large hole at $180^{\circ}$ longitude are large positive anomalies then Urey's theory of impacting planetesimals for the mascons is realistic and the lava mechanism needs reevaluation. Relay satellites or a gradiometer in a low circular polar orbit would be ideal. Also combining Soviet data would be helpful if it could be made available."

\section{INTER-UNION WORKING PARTY ON LUNAR LASER RANGING EXPERIMENTS}

A joint COSPAR-IAU Working Party on Lunar Laser Ranging, under the Chairmanship of C. O. Alley, was appointed in 1970. In 1971, the International Union of Geodesy and Geophysics (I.U.G.G.) decided to get involved in this cooperation, as a special study group of I.A.G. (International Association of Geodesy).

The U.S.S.R. laser program is conducted in cooperation with France. A French laser retroreflector was placed on the Moon in the Lunakhod roving vehicle of the mission "Luna 17". Laser echoes were collected from the U.S.S.R. station of Crimea and the French Observatory Pic-duMidi, although the lunar dust raised by the motion of Lunakhod on the Moon reduced quickly the reflecting power of the mirrors.

The U.S. program was conducted by the U.S. National Group "Lunar Ranging Experiment Team (LURE)" under the Chairmanship of J. E. Faller. The following report is from P. L. Bender: 